\title{
24-hour nutrient mass balance of small storage reservoir included in municipal rainwater drainage system
}

\author{
Maciej Ziułkiewicz ${ }^{1}$, Michat Górecki ${ }^{2,}$, Anna Fortuniak ${ }^{1}$, Aneta Walas ${ }^{3}$, and Rafat Grulke ${ }^{3}$ \\ ${ }^{1}$ Laboratory of Geology, University of Łódź, 90-139 Łódź, ul. Narutowicza 88, Poland \\ ${ }^{2}$ Fourth year of doctoral studies, the Faculty of Geographical Sciences, University of Łódź, 90-139 \\ Łódź, ul. Narutowicza 88, Poland \\ ${ }^{3}$ Third year of full-time studies in the field of Geomonitoring, the Faculty of Geographical Sciences, \\ University of Łódź, 90-139 Łódź, ul. Narutowicza 88, Poland
}

\begin{abstract}
The paper presents the results of research, which aimed at tracing the quantitative and qualitative effect of the "Tomaszowska" urban retention reservoir (located in the Łódź city) on the Olechówka River flowing through it over a period of one day. For this purpose, two measurement-control points were established located directly above the inflow of river to the reservoir, and below the weir. Hydrological and hydrochemical measurements were performed every two hours. Results obtained in this research present the reservoir as an object that in terms of the inflowing river, among others, in a daily balance of pollutants retains mineral and biogenic compounds, and releases dissolved and suspended organic compounds, and also changes the structure of pollution (in the case of total dissolved solids and total nitrogen, increasing the contribution of their organic forms).
\end{abstract}

\section{Introduction}

The Olechówka River in the administrative boundaries of Łódź fulfils the function of a recipient of stormwaters. Several retention reservoirs exist along its course, fulfilling different economic functions. From the point of view of the state of water quality in the river, the "Tomaszowska" reservoir is the most interesting. It was established for the regulation of discharges of the river below the outlet of a large stormwater collector from the Widzew borough, and for the protection of water quality in the "Młynek" reservoir located below, retaining water for recreational purposes.

Research on the Olechówka River showed that the "Tomaszowska" reservoir is an important element affecting river water quality in conditions of water level increases caused by precipitation [1], as well as during the flow of the same part of river water from the „sources" to the mouth - with consideration of the time of water retention in the reservoir [2].

* Corresponding author: michal.gorecki@geo.uni.lodz.pl 
The research on the "Tomaszowska" reservoir was based on results of hydrochemical research conducted in 2017 involving the determination of the daily variability of pollution indicators in two profiles established on the course of the Olechówka River, representing the weakest and strongest transformed sections of its channel [3]. Research implemented in 2018 aimed at tracing the quantitative and qualitative effect of the urban retention reservoir on the river flowing through it over a period of one day - with no consideration of the retention time. Like in previous years, the works were implemented with the participation of students of major Geomonitoring at the Faculty of Geographic Sciences of the University of Łódź.

The consideration of the role of the retention reservoir in the determination of the daily variability of hydrochemical parameters of river waters in the current research aims at capturing this among other factors determining water quality in the urban catchment.

\section{Study object}

The "Tomaszowska" reservoir was established in 1972 through damming of the Olechówka River a concrete weir on $\mathrm{km} 9+350$ of the course of the river. The reservoir occupies an area of $1.20 \mathrm{ha}$, and at a constant damming ordinate on the weir (199.5 m a.s.1.), it has a volume of approximately 17.5 thousand $\mathrm{m}^{3}$ [4]. The catchment of the reservoir with an area of $15.5 \mathrm{~km}^{2}$ is occupied by: a metropolitan residential district Olechów, industrial and warehouse areas of Dąbrowa, and a cargo railway station PKP Łódź-Olechów (Fig. 1). The catchment sealing coefficient varies from 0.2 for residually preserved agricultural areas to 0.6 for the residential district. The weighted average for the catchment of the "Tomaszowska" reservoir is 0.45 . The Olechówka River channel on the inflow to the reservoir features heavy bank enforcements (UTC-1) in the form of concrete slabs, and biological enforcements were applied below the reservoir (UB) [4]. On the section from the beginning of the river to the "Tomaszowska" reservoir is located smaller reservoir named «Upper Olechówka » with automatically regulated outflow. Moreover are total of 12 outlets of drainage ditches (2) and sewage collectors (10) function along the course of the Olechówka River [2].

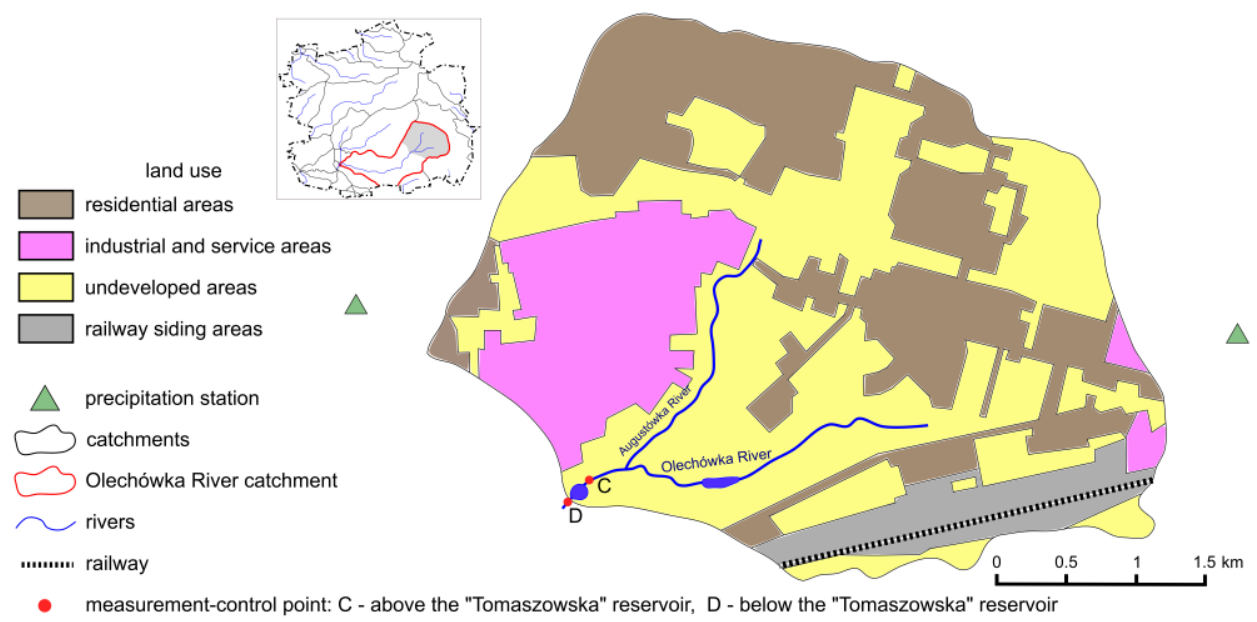

Fig. 1. Land development in the catchment of the "Tomaszowska" reservoir and location of measurement-control points. 


\section{Study methodology}

The research in 2018 was conducted over one day, from 8:00 on 23 May to 8:00 of the following day at a measurement-control point (mcp) located directly above the inflow of the Olechówka River to the reservoir (C), and at a mcp located below the weir (D) (Fig. 1). Water samples were collected at those sites every two hours for determinations of ions $\mathrm{NH}_{4}^{+}, \mathrm{NO}_{2}^{-}$, $\mathrm{NO}_{3}{ }^{-}$, and $\mathrm{PO}_{4}{ }^{3-}$, total nitrogen (TN), and total phosphorus (TP), as well as total suspension (Susp.), oxidability (COD-Mn), and total dissolved solids (TDS). During sampling, the following physical-chemical water parameters were recorded: temperature (Temp.), reaction $(\mathrm{pH})$, standardized electrolytic conductivity (SEC), and dissolved oxygen (DO). Hydrochemical observations were supplemented by the measurement of discharge rate (Q) in the Olechówka River by means of a current meter. The research was first implemented at a mcp C, and then after approximately $0.5 \mathrm{~h}$ at a mcp D. A two-hour time step was applied in measurements and analyses, because it was assumed that during low water stages caused by a longer period with no precipitation in the catchment, fluctuations of values of hydrochemical parameters will not be high [3], and that the conditions of low flow can be maintained in a river for a long time, hence the quality of its waters is an important factor affecting the health condition of water organisms [5]. Chemical analyses of the collected river water samples were performed at the laboratory of Laboratory of Geology and at the laboratory of the Collective Sewage Treatment Plant in Łódź. The statistical calculations of the obtained results employed Statistica 13.1. software.

\section{Results}

Discharges in the Olechówka River were within the following ranges: 9.4-27.4 $\mathrm{L} \cdot \mathrm{s}^{-1}$ at a mcp C, and 16.0-23.2 L·s ${ }^{-1}$ at a mcp D (Fig. 2). Considering the volume of the reservoir, this provides for an average time of water retention of 10 days and 19 hours. Between 8:00 on 23 May and 8:00 on 24 May, a total of $1356 \mathrm{~m}^{3}$ of water was supplied to the reservoir, and $1622 \mathrm{~m}^{3}$ was discharged, i.e. $266 \mathrm{~m}^{3}$ more. Notice the evident increase in the amount of inflowing water that occurred between 18:00 and 22:00. According to data provided by the Department of Meteorology and Climatology of the University of Łódź, no atmospheric precipitation was recorded at any of the precipitation stations located in immediate vicinity the catchment of the "Tomaszowska" reservoir over 4 days preceding the hydrochemical research.

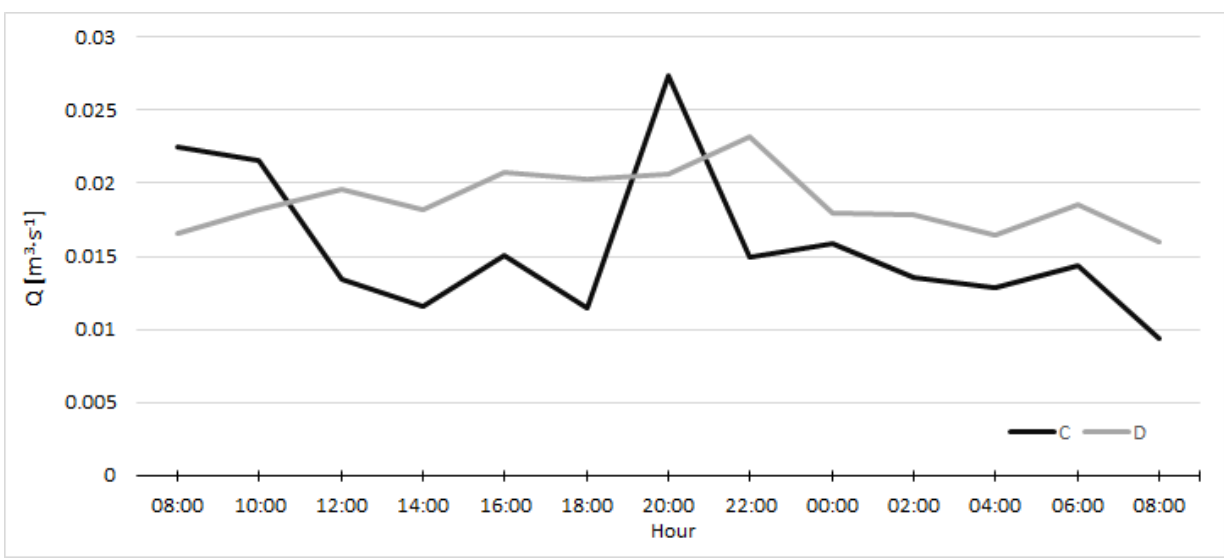

Fig. 2. Changes in discharge rate $(\mathrm{Q})$ in the Olechówka River above (C) and below (D) the "Tomaszowska" reservoir during the study day. 
Waters flowing out of the reservoir were warmer, better oxygenated, and contained more suspension (Table 1). The remaining parameters were higher in inflowing waters. The reservoir evidently stabilised the physical-chemical daily variability of the Olechówka River. An exception was the slightly higher variability of the $\mathrm{pH}$ and variability of Susp. and COD$\mathrm{Mn}$ on the outflow.

Table 1. Physical-chemical characteristics of the waters of the Olechówka River above (C) and below (D) the "Tomaszowska" reservoir.

\begin{tabular}{|c|c|c|c|c|c|c|}
\hline & \multicolumn{3}{|c|}{ mcp C } & \multicolumn{3}{|c|}{ mcp D } \\
\hline parameter & Mean & SD & $\mathrm{CV}[\%]$ & Mean & SD & $\mathrm{CV}[\%]$ \\
\hline Temp. $\left[{ }^{\circ} \mathrm{C}\right]$ & 17.14 & 2.60 & 15.1 & 20.45 & 1.53 & 7.5 \\
\hline $\mathrm{SEC}\left[\mu \mathrm{S} \cdot \mathrm{cm}^{-1}\right]$ & 606.60 & 58.10 & 9.6 & 508.80 & 23.14 & 4.5 \\
\hline $\mathrm{pH}[-]$ & 7.56 & 0.18 & 2.4 & 7.53 & 0.31 & 4.1 \\
\hline $\mathrm{DO}\left[\mathrm{mg} \cdot \mathrm{dm}^{-3}\right]$ & 5.29 & 0.63 & 11.9 & 6.68 & 0.30 & 4.5 \\
\hline Susp. $\left[\mathrm{mg} \cdot \mathrm{dm}^{-3}\right]$ & 5.38 & 1.50 & 27.9 & 9.00 & 3.76 & 41.8 \\
\hline COD-Mn $\left[\mathrm{mgO}_{2} \cdot \mathrm{dm}^{-3}\right]$ & 9.09 & 0.47 & 5.1 & 8.48 & 1.27 & 15.0 \\
\hline $\mathrm{NH}_{4}^{+}\left[\mathrm{mg} \cdot \mathrm{dm}^{-3}\right]$ & 0.44 & 0.61 & 137.5 & 0.23 & 0.04 & 15.6 \\
\hline $\mathrm{NO}_{2}^{-}\left[\mathrm{mg} \cdot \mathrm{dm}^{-3}\right]$ & 0.16 & 0.03 & 21.0 & 0.17 & 0.03 & 16.3 \\
\hline $\mathrm{NO}_{3}{ }^{-}\left[\mathrm{mg} \cdot \mathrm{dm}^{-3}\right]$ & 3.57 & 1.37 & 38.4 & 1.67 & 0.61 & 36.4 \\
\hline $\mathrm{TN}\left[\mathrm{mg} \cdot \mathrm{dm}^{-3}\right]$ & 3.83 & 2.36 & 61.7 & 2.45 & 0.17 & 7.1 \\
\hline $\mathrm{PO}_{4}^{3+}\left[\mathrm{mg} \cdot \mathrm{dm}^{-3}\right]$ & 0.89 & 0.14 & 15.6 & 0.69 & 0.09 & 13.5 \\
\hline $\mathrm{TP}\left[\mathrm{mg} \cdot \mathrm{dm}^{-3}\right]$ & 0.26 & 0.12 & 47.2 & 0.17 & 0.02 & 10.4 \\
\hline
\end{tabular}

Notice: Highest values are in highlighted

The hydrochemical interpretation of the variability of $\mathrm{Q}$ in the Olechówka River employed similarity analysis by means of the Ward agglomeration method. The degree was identified to which the hydrochemical state of waters from particular sampling hours shows mutual similarity in terms of: $\mathrm{pH}, \mathrm{SEC}, \mathrm{DO}$, Susp., COD-Mn, TP, $\mathrm{NH}_{4}^{+}$, and $\mathrm{NO}_{3}{ }^{-}$ concentrations (Fig. 3). They are elements which according to earlier studies [1-3] reflected the specificity of pollution of the Olechówka River in its urban catchment.

a)

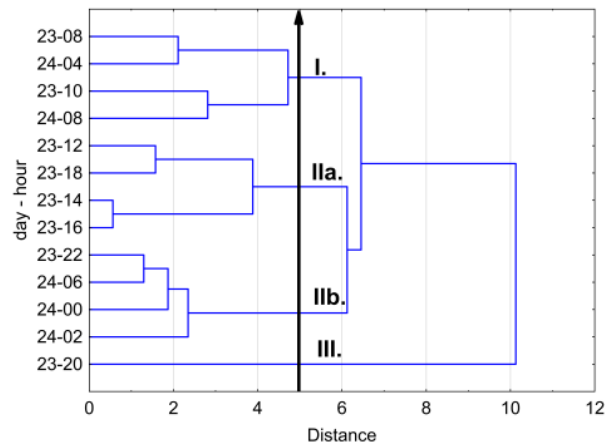

b)

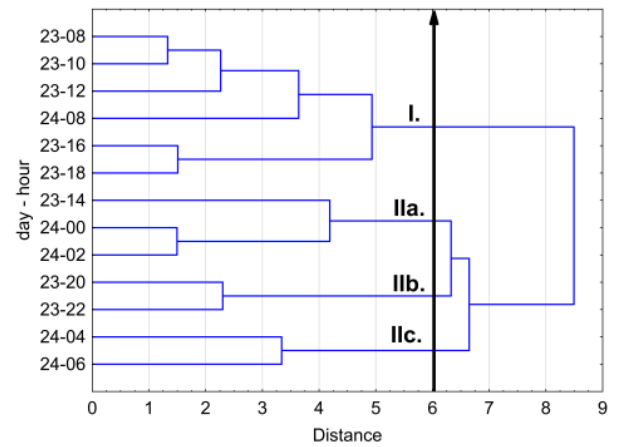

Fig. 3. Dendrograms of similarity of moments of water sampling in the Olechówka River on the inflow to the "Tomaszowska" reservoir ( $\operatorname{mcp} \mathrm{C}-\mathbf{a})$, and on the outflow (mcp D $-\mathbf{b})$. Vectors point to the designation of groups of cases based on the analysis of the graph of the agglomeration course [6], Roman digits with a letter index mark selected groups of cases.

Groups of cases designated in the dendrograms were considered as hydrochemical states of the waters of the Olechówka River characteristic on a given measurement day for the site above and below the reservoir. Their representation on the graph of river discharge 
fluctuations at both mcp is presented in Figure 4, and mean values of hydrochemical parameters for each designated state are provided in Table 2.

a)

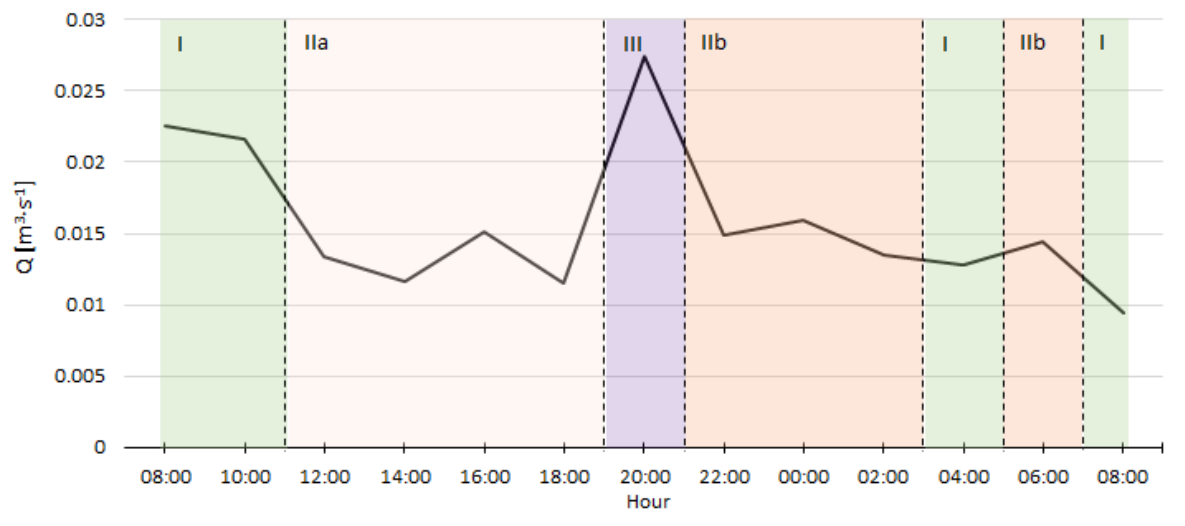

b)

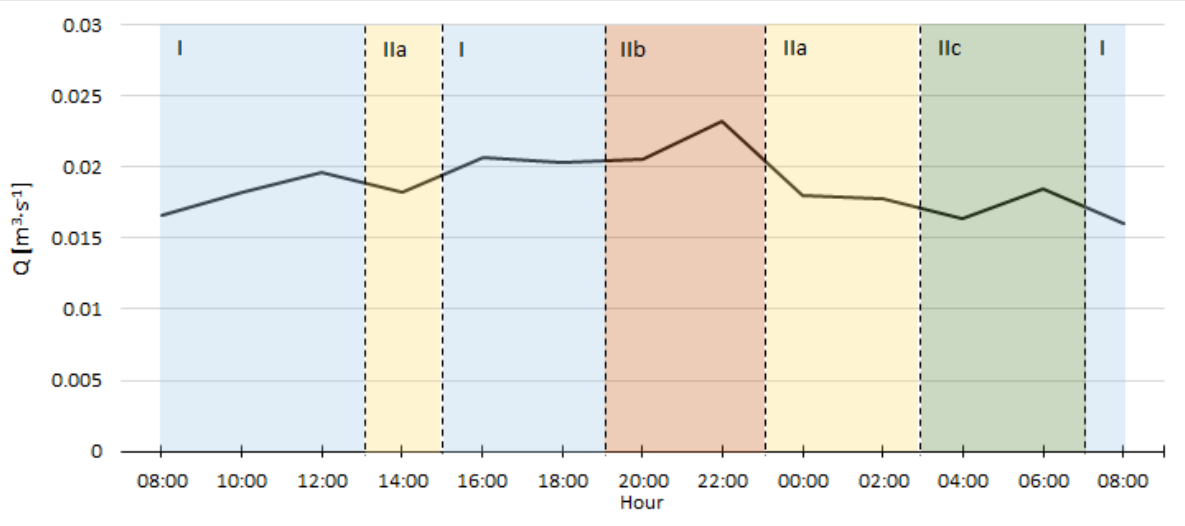

Fig. 4. Hydrochemical states of the waters of the Olechówka River above (a) and below (b) the "Tomaszowska" reservoir during the study day 23-24.05.2018.

In the waters of the Olechówka River inflowing to the reservoir, the daily hydrochemical axis is the water level increase at 20:00. At that time, the water reached the worst quality parameters (maximum values of almost all parameters, except for oxygen the concentration of which reached the minimum). Before the water level increase, the water showed the best quality parameters - reaching minimum values of indices, except for DO and Temp. that reached daily maximums. Directly after the water level increase, the state evidently deteriorated. This dominant course of quality fluctuations also overlaps with the effect of the earlier water level increase (at 8:00-10:00) with a lower degree of water contamination than in the case of the water level increase from 20:00.

The warmest waters flew out of the reservoir between 20:00 and 22:00. With the highest amount of water flowing through the weir, the maximum oxygenation and highest load of Susp. also occurred (bioseston?). They were waters with the minimum concentration of $\mathrm{NH}_{4}{ }^{+}$ and the highest concentration of $\mathrm{NO}_{3}{ }^{-}$(evidence of effective nitrification during the day). The coolest waters flew out of the reservoir between 4:00 and 6:00. The lowest DO concentration occurred at the time (after the night), as well as the highest SEC, lowest $\mathrm{pH}$, and highest daily concentrations of $\mathrm{TN}, \mathrm{TP}, \mathrm{NH}_{4}{ }^{+}$, and COD-Mn. In the morning 
(8:00-12:00) and afternoon (16:00-18:00), the waters show the lowest SEC, and the lowest concentrations of $\mathrm{TN}, \mathrm{TP}$, and $\mathrm{NO}_{3}{ }^{-}$.

Table 2. Mean values of water quality parameters in the Olechówka River calculated for the designated hydrochemical states.

\begin{tabular}{|c|c|c|c|c|c|c|c|c|c|c|c|}
\hline state & $\alpha \stackrel{\infty}{\Xi}$ & H & 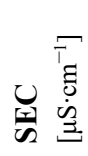 & 플 & 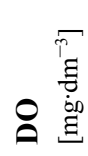 & 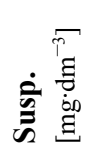 & 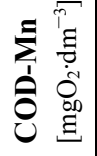 & 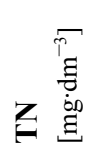 & 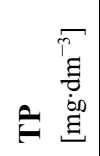 & 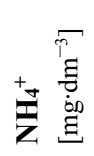 & ' \\
\hline \multicolumn{12}{|c|}{ Inflow to the reservoir (mcp C) } \\
\hline I & 0.016 & 17.1 & 602 & 7.6 & 5.2 & 5 & 9.1 & 3.83 & 0.26 & 0.443 & 3.569 \\
\hline IIa & 0.013 & 20.6 & 582 & 7.6 & 5.8 & 4 & 8.9 & 2.84 & 0.20 & 0.176 & 2.420 \\
\hline IIb & 0.015 & 15.1 & 600 & 7.7 & 4.9 & 5 & 9.6 & 3.24 & 0.24 & 0.377 & 3.143 \\
\hline III & 0.027 & 17.0 & 728 & 7.8 & 4.7 & 9 & 9.2 & 11.50 & 0.65 & 2.438 & 6.021 \\
\hline \multicolumn{12}{|c|}{ Outflow from the reservoir (mcp D) } \\
\hline I & 0.019 & 20.7 & 498 & 7.6 & 6.7 & 8 & 8.8 & 2.36 & 0.15 & 0.228 & 1.257 \\
\hline IIa & 0.018 & 20.4 & 517 & 7.7 & 6.7 & 7 & 7.0 & 2.53 & 0.18 & 0.239 & 2.073 \\
\hline IIb & 0.022 & 21.2 & 529 & 7.5 & 6.9 & 16 & 8.8 & 2.44 & 0.17 & 0.176 & 2.614 \\
\hline IIc & 0.017 & 18.8 & 545 & 7.3 & 6.4 & 9 & 9.4 & 2.62 & 0.19 & 0.283 & 1.357 \\
\hline
\end{tabular}

From the reservoir the water level decreased two hours later in reference to inflow. The excess waters leaving the reservoir $(\mathrm{mcp} \mathrm{C}-I I b)$ were more than $4^{\circ} \mathrm{C}$ warmer than excess waters flowing into the reservoir (mcp D - III), they had SEC lower by $200 \mu \mathrm{S} \cdot \mathrm{cm}^{-1}$, DO concentration higher by more than $2 \mathrm{mg} \cdot \mathrm{dm}^{-3}$, higher Susp. concentration, somewhat lower COD-Mn, and considerably lower concentrations of biogenic indices.

The measurement of $\mathrm{Q}$ in the river with the determination of concentrations of quality indicators permits the identification of pollution loads supplied and discharged from the reservoir. Their daily balance (Fig. 5) suggests that the "Tomaszowska" reservoir retains mineral and biogenic compounds, and releases organic compounds measured by TDS, COD$\mathrm{Mn}$, and Susp. Due to the structure of the weir allowing discharge of water from the surface layer of the reservoir, the last parameter seems to represent bioseston.

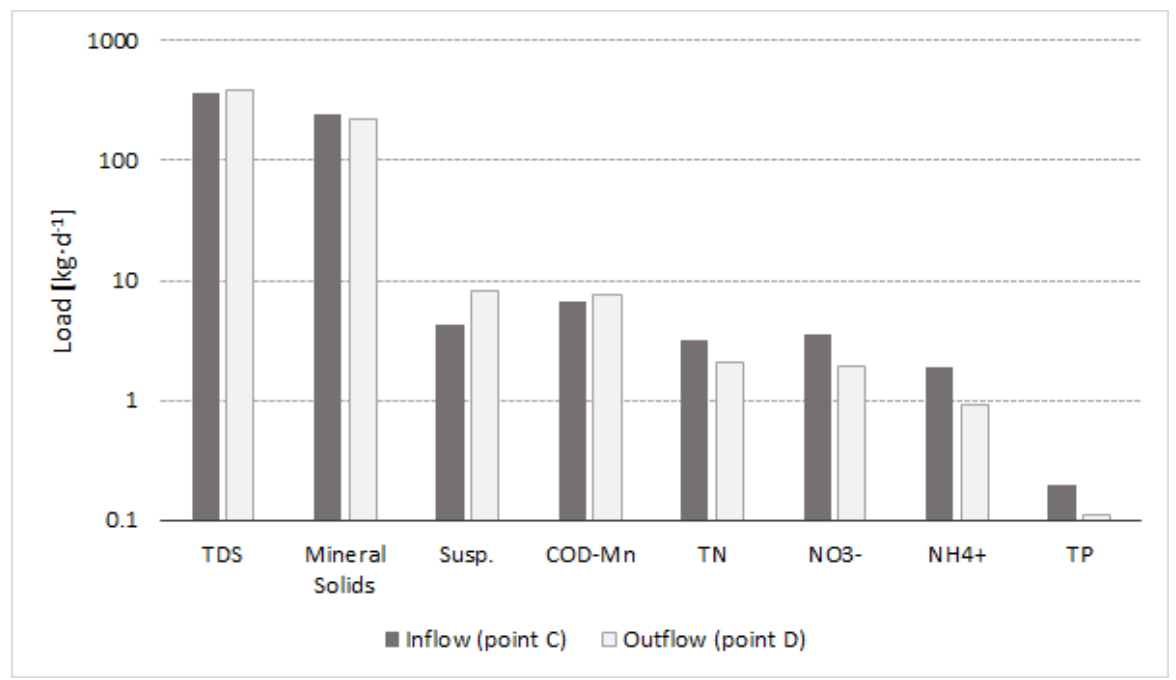

Fig. 5. Daily load of pollutants supplied and discharged from the "Tomaszowska" reservoir through the Olechówka River. 
The mean daily composition of TDS, with separation of mineral and organic substances, and composition of $\mathrm{TN}$, with designation of mineral nitrogen and dissolved nitrogen, is presented in Table 3 .

Table 3. Mean daily composition of TDS and TN with designation of mineral and organic components in the waters of the Olechówka River above (C) and below (D) the "Tomaszowska" reservoir.

\begin{tabular}{|c|c|c|c|c|}
\hline study site & mineral solids & organic components & mineral nitrogen & organic nitrogen \\
\hline inflow $(C)$ & $66.7 \%$ & $33.3 \%$ & $72.5 \%$ & $27.5 \%$ \\
\hline outflow $(D)$ & $59.2 \%$ & $40.8 \%$ & $55.7 \%$ & $44.3 \%$ \\
\hline
\end{tabular}

The reservoir slightly changes the structure of runoff of TDS in the Olechówka River, inconsiderably increasing the contribution of dissolved organic substances. In the case of TN the change is more evident in favour of organic nitrogen which almost balances the mineral forms.

\section{Conclusions and discussion}

Daily comparative research on water flowing in and out of a reservoir is assumed to provide a possibility to capture the state of waters flowing through the reservoir over a considerably shorter time than in the case of comparison of its volume and mean outflow rate. The research conducted in 2016 [2], taking the time into account, showed a significant increase in the load of the Olechówka River with pollutants discharged from the reservoir. For example, among others a two-fold increase in TN, TP, and $\mathrm{NH}_{4}^{+}$concentrations occurred, as well as a four-fold increase in COD-Mn, and approximately 40 -fold increase in Susp. Results obtained in 2018 present the reservoir as an object that in terms of the inflowing of the Olechówka River:

- reduces daily fluctuations of values of hydrochemical parameters, with the exception of Susp., COD-Mn, and $\mathrm{pH}$;

- modifies the hydrochemical image of water level increases, reducing the load of the waters of the Olechówka River with dissolved, organic, and biogenic substances, with the exception of Susp.;

- in a daily balance of pollutants retains mineral and biogenic compounds, and releases dissolved and suspended organic compounds;

- changes the structure of pollution, in the case of TDS and TN, increasing the contribution of their organic forms.

The captured changes in the quality of the waters of the Olechówka River above and below the "Tomaszowska" reservoir are in accordance with the observations by [7] and [8] regarding fluctuations of concentrations and loads of biogenic substances in small retention reservoirs in urban and suburban areas. The "Tomaszowska" reservoir proved to be an effective "biogenerator" assimilating mineral forms of nutrients, and simultaneously releasing products of their biochemical transformations by aquatic vegetation to the Olechówka River in the form of dissolved and suspended organic matter.

The water level increase recorded at 20:00 on 23 May deserves attention. It was not caused by precipitation, because no precipitation was recorded in the nearby meteorological stations. It was probably result of discharge of contaminants of a different origin from one of a dozen sewage collectors having their outlets in the Olechówka River channel above the "Tomaszowska" reservoir. The load of pollutants discharged in the Olechówka River at the time constituted a considerable part of the daily load: $35 \%$ TN and 30\% TP, 21\% Susp., 14\% TDS, and $13.5 \%$ substances represented by COD-Mn. This observation confirms the research 
experience from 2017 [3], when the most dynamic hydrochemical fluctuations were determined to occur in the Olechówka River in the evening and by night.

In terms of the recorded dynamics of fluctuations of hydrochemical parameters, the study sites on the Olechówka River located above and below the "Tomaszowska" reservoir corresponded with the dynamics of changes documented in 2017 in the profile at the Zygmunta Street - representing a more natural section of the Olechówka River [3]. With the exception of $\mathrm{pH}$ and COD-Mn which below the "Tomaszowska" reservoir were characterised by the highest daily dynamics of fluctuations in all four profiles of the Olechówka River (studied jointly in 2017 and 2018), the most hydrochemically variable profile in a daily scale was that at the Podmokła Street, located somewhat above the inflow of the Olechówka River to the Jasień River.

\section{References}

1. M. Ziułkiewicz, A. Fortuniak, A. Waack-Zając, M. Górecki, S. Grzędzińska, B. Małecka, Monografie Komitetu Gospodarki Wodnej Polskiej Akademii Nauk 39, 279-291 (2016)

2. T. Bagrowicz, A. Fortuniak, M. Górecki, M. Lewandowska, M. Ziułkiewicz, E3S Web of Conferences 17, 00002 (2017)

3. A. Fortuniak, K. Hałas, M. Górecki, K. Szewczyk, A. Wojtania, M. Ziułkiewicz, E3S Web of Conferences 44, 00042 (2018)

4. M. Zalewski, J. Bocian, M. Zawilski, G. Sakson, I. Kujawa, Projekt generalny rzeki Olechówki. Projekt generalny rzek dla miasta Łodzi - zlewnie rzeki Ner, rzeki Miazgi i rzeki Bzury-R-2 (Biuro Inżynierii Wodnej, Środowiska i Melioracji AQUAPROJEKT, Łódź, 2000)

5. R.B. Grayson, C.J. Gippel, B.L. Finlayson, B.T. Hart, J. Hydrol. 199, 121-134 (1997)

6. A. Stanisz, Przystępny kurs statystyki z zastosowaniem STATISTICA PL na przykładach z medycyny, t. 3, Analizy wielowymiarowe (StatSoft, Kraków, 2007)

7. R. Gołdyn, Zmiany biologicznych i fizyczno-chemicznych cech jakości wody rzecznej pod wplywem jej piętrzenia we wstępnych, nizinnych zbiornikach zaporowych (Wydawnictwo Naukowe UAM, Poznań, 2000)

8. A.R. Ignatius, T.C. Rasmussen, J. Hydrol. Reg. Stud. 8, 145-161 (2016) 